\title{
A Check List for Evaluating Persuasive Features of Mathematics
} Courseware

\author{
Baharuddin Aris ${ }^{1}$, Alireza Gharbaghi ${ }^{2}$, Maizah Hura Ahmad ${ }^{3} \&$ Mohd Shafie Rosli ${ }^{4}$ \\ ${ }^{1}$ Centre for Teaching and Learning, Universiti Teknologi Malaysia (UTM), Johor, Malaysia \\ ${ }^{2}$ Faculty of Education, Universiti Teknologi Malaysia (UTM), Johor, Malaysia \\ ${ }^{3}$ Faculty of Science, Universiti Teknologi Malaysia (UTM), Johor, Malaysia \\ ${ }^{4}$ Faculty of Education, Universiti Teknologi Malaysia (UTM), Johor, Malaysia \\ Correspondence: Alireza Gharbaghi, Faculty of Education, UTM, Johor, Malaysia. Tel: 60-177-852-016. E-mail: \\ Alireza_Gharbaghi@yahoo.com
}

Received: July 16, 2013 Accepted: July 30,2013 Online Published: August 29, 2013
doi:10.5539/ies.v6n9p125
URL: http://dx.doi.org/10.5539/ies.v6n9p125

\begin{abstract}
The main propose of this study is to introduce a check list for evaluating persuasive features of mathematics courseware. Since, mathematics is a source of anxiety among students (Zeidner \& Matthews, 2010), this research is an attempt to employ persuasive features that can be used in mathematics courseware. Specifically, we sought to determine criteria that are important for persuading learners; and to ascertain persuasive factors have this ability that employed in computer based mathematics learning. These features originated 13 different prior persuasive models, theories, and approaches that are categorized in seven groups. Content Analysis was used to extract 16 features. For reporting results of Content Analysis method, were conducted 9 research steps. In the next step, the check list was prepared by using extracted persuasive principals with 16 criteria. So, three of more popular mathematics courseware in Iran, were evaluated by new designed check list; and are reported the results. The results have shown the most popular mathematics courseware which its name is "Kusha \& Misha", could only earned approximately half of check list points. Two others courseware only be able to obtain a third of persuasive points. Totally, it can be concluded that, with more regard to the persuasion, perhaps we can overcome on negative attitudes toward mathematics in school students.
\end{abstract}

Keywords: negative attitude toward mathematics, check list, persuasion, persuasive technology

\section{Introduction}

In the recent years, a large number of tasks, duties and roles have been given to computers. Today, we can see them in variety roles as persuaders, including influencing roles that usually were filled by teachers, coaches, clergies, doctors, and sellers, among others. In fact, we have entered an era of persuasive technology. persuasive technology is a new version of persuasive theories and models where changing attitudes or behaviors of people (Perloff, 2010). It should be noted that we are still in the early stages of persuasive technology development whereas the potential of such technology is enormous (Fogg, 2003). Hence, persuasive technology is as an example of technological apparatus, have entered in various aspects of educational issues, learning processes, and classroom activities. According to Perloff (2010) definition, persuasion is a symbolic process in which communicators try to convince other people to change their attitudes or behavior regarding an issue through the transmission of a message in an atmosphere of free choices. At a glance, it seems two main factors in this process are including: trying to change receiver/s attitudes or behavior and transmission of a message in an atmosphere of free choices.

Over the last decades, investigators in various filed of education have recognized a variety of students attitude toward different subjects, specially mathematics (Aiken, 1970; Gunderson, Ramirez, Levine, \& Beilock, 2012; Hong, 2010; Hossain \& Quinn, 2013; Lim \& Chapman, 2013; Pilli \& Aksu, 2012; Silverman \& Subramaniam, 1999; Wong \& Chen, 2012; Zakaria, Chin, \& Daud, 2010). Mathematical skills are needed for managing even ordinary human relations (Ernest, Greer, \& Sriraman, 2009; Kail \& Cavanaugh, 2012). However, academic failure is one of the main problems in the educational systems especially in mathematics (Connor, 2012; Wendling \& Mather, 2008; Zeidner \& Matthews, 2010). Thus, In spite of increasing mathematics training plans, 
methods, and strategies, the outcome is less satisfactory. Because, previous studies have shown, students' achievement in mathematics is affected by several factors such as the environment of the school, which must be favorable (Creemers \& Reezigt, 2005), teaching and learning process (Tall, 1993; Van de Grift \& Houtveen, 2006), gender differences (Stipek \& Gralinski, 1991) school programs (Beghetto, 2010) and so forth. Also, the conceptions, attitudes, and expectations of the students regarding mathematics and mathematics teaching have been considered as very significant factor underlying their school experience and achievement (Borasi, 1996; Dogan, 2012; Reed, Drijvers, \& Kirschner, 2010; Schoenfeld, 1985). Yet the subject of mathematics, although revered, remains a source of anxiety and trepidation for a large number of students (Zeidner \& Matthews, 2010). Therefore, it seems positive attitude towards mathematics can leads students towards success in this subject. Hence, attempt to improve attitude towards mathematics at lower level provides a base for higher studies in mathematics.

Nowadays, several capabilities have been recognized in computer-based learning (CBL) environments. However, there are two critical drawbacks about them. First, the lack of the instructor; second the absence of motivation. These drawbacks seem to be reason for drop-out in CBLs (Yamada, 2009). The lack of the instructor may result in two problems. First, reduction of learners' consciousness regarding the necessity of study, as the learners feels no necessity to attend classroom. They have the chance to give priority to their personal affairs, which may lead to failure in the course (Bersin, 2004). Second, is feedback; in absence of an instructor, a reduction in appropriate and immediate feedback is expected (Bulter \& Winne, 1995; Lou, Dedic, \& Rosenfield, 2003). Thus, a system that supports learning consciousness is essential when no instructor is available in the learning environment.

Totally, it seems that to focus on persuasion and related matters in CBLs can be a solution to overcome mentioned problems. According to Pierce and Stacey (2004) findings, students with positive attitudes towards mathematics and mathematical computer tools overcome initial difficulties when using such a tool and progressed to more effective behaviors, such as using the tool to explore and develop their conceptual understanding. Moreover, differences between learners such as learners' differences in earlier knowledge, abilities, skills, and differences in affective variables (such as motivation) have an important role in the development of supportive learning environments (Vandewaetere, Desmet, \& Clarebout, 2011). Thus, the main purpose of this study is to introduce a check list for evaluating persuasive features of mathematics courseware. Previous studies have shown high attitude toward a specific subject or matter in schools is a helpful factor to high achievement (McCoach \& Siegle, 2001; Sankofa, Hurley, Allen, \& Boykin, 2005). Since, there is no check list and no criterion to evaluate the ability of mathematics courseware to persuading students, this study is introduced an applicable check list for gaining this aim. So, at the first step, 13 different persuasive models, theories, and models in seven groups reviewed (Cameron, 2009; Fogg, 2003); and their principals were extracted. The extracted principals were a base to design the check list. In the next steps, validity and reliability of the check list were examined. The research process in the next sections will be illustrated.

\section{Method}

In this study Content Analysis was used to collect data. Briefly, Content Analysis is defined as the systematic, objective, quantitative analysis of message characteristics. It includes careful examination of human interactions (Neuendorf, 2002). He explains this method is included nine consecutive steps which they are Theory and Rationale, Conceptualization, Operationalization, Coding, Sampling, Training and pilot reliability, Coding, Final reliability, Tabulation and reporting. Based on final codes, the checklist prepared. This checklist included 16 criteria for evaluating persuasive features of mathematics courseware. Last step in this part of study was checklist validity.

\section{Results}

At the first step of Content Analysis method, the history of persuasive models, theories, and approaches reviewed. The principals of 13 prior persuasive models, theories, and approaches in seven groups are extracted. The results of this extraction are shown in Table 1 . These principals are categorized based on their origin models, theories, and approaches. 
Table 1. Operating principles and concepts of persuasion models, theories and approaches

\begin{tabular}{|c|c|c|}
\hline $\begin{array}{l}\text { Categories of } \\
\text { Models, Theories } \\
\text { and approaches }\end{array}$ & Models Names & principles and concepts of persuasion \\
\hline $\begin{array}{l}\text { Message Effects } \\
\text { Model }\end{array}$ & $\begin{array}{l}\text { Yale Model (Hovland, Janis, \& } \\
\text { Kelley, 1953) }\end{array}$ & $\begin{array}{l}\text { Need to a clear message, presenting } \\
\text { message in a new way, assent of } \\
\text { message by recipient }\end{array}$ \\
\hline $\begin{array}{l}\text { Attitude Behavior } \\
\text { Approaches }\end{array}$ & $\begin{array}{l}\text { Theory of Reasoned Action } \\
\text { (Fishbein \& Ajzen, 1975) } \\
\text { Theory of Planned Behavior } \\
\text { (Ajzen \& Sozialforschung, 2000) } \\
\text { Triandis Model of Interpersonal } \\
\text { Behavior (Triandis, 1989) }\end{array}$ & $\begin{array}{l}\text { Attention to recipients' attitude and } \\
\text { believes, to create new motivations, } \\
\text { present new concepts and knowledge, } \\
\text { attention to social norms }\end{array}$ \\
\hline $\begin{array}{l}\text { Cognitive } \\
\text { Processing } \\
\text { Theories and } \\
\text { Models }\end{array}$ & $\begin{array}{l}\text { Elaboration Likelihood Model } \\
\text { (Petty \& Cacioppo, 1986) } \\
\text { Heuristic-Systematic Model } \\
\text { (Chaiken \& Trope, 1999) } \\
\text { Social Judgment Theory (Sherif, } \\
\text { Sherif, \& Neber- gall, 1965) }\end{array}$ & $\begin{array}{l}\text { Increase the knowledge, creativity and } \\
\text { innovation in the presentation, } \\
\text { possibility to change in the conditions, } \\
\text { using past knowledge, fixing defects } \\
\text { and solving problems, to create testing } \\
\text { ability }\end{array}$ \\
\hline $\begin{array}{l}\text { Consistency } \\
\text { Theories }\end{array}$ & $\begin{array}{l}\text { Balance Theory (Heider, 1982) } \\
\text { Cognitive Dissonance Theory } \\
\text { (Festinger, 1957) } \\
\text { Probabilogical Models (W. } \\
\text { McGuire, 1981) }\end{array}$ & $\begin{array}{l}\text { Attitudes towards subject, attitudes } \\
\text { towards presenter, possibility to change } \\
\text { in forming elements, present new } \\
\text { knowledge, presenting importance of } \\
\text { subject, Presenting logical deduction, } \\
\text { concluding based on reasons }\end{array}$ \\
\hline $\begin{array}{l}\text { Inoculation } \\
\text { Theory }\end{array}$ & $\begin{array}{l}\text { Inoculation Theory (W. J. } \\
\text { McGuire, 1964) }\end{array}$ & $\begin{array}{l}\text { Presenting logical reasons for new } \\
\text { issues, presenting in the appropriate } \\
\text { conditions }\end{array}$ \\
\hline $\begin{array}{l}\text { Functional } \\
\text { Approaches }\end{array}$ & $\begin{array}{l}\text { Functional Approaches (Katz, } \\
\text { 1960; Smith, Bruner, \& White, } \\
\text { 1956) }\end{array}$ & $\begin{array}{l}\text { Presenting usefulness reasons, giving } \\
\text { reward, removing punishment }\end{array}$ \\
\hline $\begin{array}{l}\text { Computer Based } \\
\text { Approaches }\end{array}$ & Captology Theory (Fogg, 2003) & $\begin{array}{l}\text { Reducing complexity, attention to } \\
\text { tunneling, providing new information } \\
\text { relevant to individuals, possibility of } \\
\text { personalization, Presenting in the } \\
\text { appropriate conditions, possibility of } \\
\text { self-evaluation, giving reward, } \\
\text { possibility of simulation situations, } \\
\text { physical cues, psychological cues, } \\
\text { language cues, social dynamics cues, } \\
\text { social role cues }\end{array}$ \\
\hline
\end{tabular}

The extracted principals were coding based on their relationships. In fact, this coding process was conducted for categorizing principals. The results of coding step, is shown in the Table 2. 
Table 2. First coding step

\begin{tabular}{lll}
\hline No. & Combined Principles and Concepts & Frequency \\
\hline 1 & $\begin{array}{l}\text { Exist of a clear message, assent of message by recipient, Presenting logical } \\
\text { deduction, concluding based on reasons, presenting usefulness reasons, }\end{array}$ & 6 \\
& $\begin{array}{l}\text { Reducing complexity } \\
2\end{array}$ & $\begin{array}{l}\text { Presenting message in a new process, increase the knowledge, presenting } \\
\text { logical reasons for new issues, present new concepts and knowledge, present }\end{array}$ \\
& new knowledge, providing new information relevant to individuals & 6 \\
3 & Attention to psychological cues, presenting in the appropriate conditions, & 4 \\
4 & presenting in the special conditions, to create new motivations & 4 \\
5 & Giving reward, removing punishment, giving reward & 3 \\
6 & Attention to social norms, attitudes towards presenter, social role cues & 3 \\
7 & Attention to recipients' attitude and believes, attitudes towards subject & 2 \\
8 & To apply language cues, social dynamics cues & 2 \\
9 & Possibility to change in forming elements,changes in physical cues, & 2 \\
10 & Possibility to change in the conditions, possibility of personalization, & 2 \\
11 & possibility of self-evaluation, to create testing ability & 2 \\
12 & Fixing defects and problems & Possibility of simulation of conditions \\
13 & Presenting importance of subject & 1 \\
14 & Using past knowledge & 1 \\
15 & Attention to tunneling process & 1 \\
16 & Creativity and innovation in the presentation & 1 \\
Total Frequency & 1 \\
\hline & & 1 \\
\hline
\end{tabular}

In the next step of research, all 13 prior models, theories and approaches were selected as research sample. Training and pilot reliability was next step of Content Analysis method. To conduct this step, three researchers reviewed the extracted codes together in a meeting discussion. These colleagues were two PH.D students and researcher who were studying in education filed. After a discussion on extracted principles, they could agree on the coding of variables. Then, in an independent coding test note the reliability on each variable. At each stage, the codebook or coding form were discussed and revised if needed. Next part was final coding; to conduct this stage of research, the investigator was prepared a codebook based on combined persuasive principles. This codebook was contained 16 different codes which they were originated of 38 principles. In fact, these 16 codes were resulted from to integrate previous models, theories, and approaches principles. Table 3 shows the results of this coding; it should be noted, these codes are prepared for using in computer-based learning environments. 
Table 3. Final coding results

\begin{tabular}{ll}
\hline Code No. & Codes' Description \\
\hline 1 & To transmission of messages, by employing rational steps and processes are effective \\
to persuade learners. \\
The contents which are presented to increase the learners' knowledge are effective for \\
persuading them. \\
Attending to learners' emotion, empathy and compassion can be effective on \\
persuade them in the learning process. \\
Giving reward and to remove unpleasant contents during learning process to learner \\
based on their performance can be effective in persuading learners. \\
Ability to produce the social roles based on social norms can be effective to persuade \\
learners. \\
Attending to learners' attitudes and beliefs can be effective in persuading them to \\
learn. \\
Providing an interactive condition in the learning process by languages cues, \\
conversations and etc. are effect to persuade learners. \\
The physical cues that are shown on display can be effective to persuade the learners \\
(i.e. faces, colors, movements). \\
Ability to personalize the display and courseware based on personal interests can be \\
effective in persuading learners. \\
Providing opportunities for self-assessment by learner during the learning process \\
can be effective in persuading learners. \\
Presenting new contents based on learner needs and problems can be effective in \\
persuading learners. \\
Providing conditions to learners for working in simulated conditions by computer can \\
be effective to persuade learners. \\
Explaining the necessity of presented content can be effective in persuading learners. \\
Consistency of new knowledge and messages with previous knowledge can be \\
effective in persuading learners. \\
To provide the conditions that to guide learners into the learning tunnel can be \\
effective to persuade learners. \\
Providing opportunities in the learning process to enable the learners to access \\
personal creativities and innovations can be effective in persuading learners.
\end{tabular}

According to these Content Analysis steps, for measuring reliability, of this coding process William Scott formula was used. Based on this formula, 20 percent of models, theories and approaches are given to three researcher (Scott, 1955). After to conduct this step, results reported as follow (See Table 4).

Table 4. Coding reliability

\begin{tabular}{ll}
\hline Researchers & Percentage of Similarity \\
\hline Researcher 1 & $\% 90$ \\
Researcher 2 & $\% 85$ \\
Researcher 3 & $\% 94$ \\
Reliability & $\alpha=.896$ \\
\hline
\end{tabular}


Based on final codes, the checklist prepared. This checklist included 16 criteria for evaluating persuasive features of mathematics courseware. Last step in this part of study was checklist validity. For doing this part of study, six experts who have had expertise in mathematics education and designing educational software are chosen. Then, the new designed check list was sent to them for collecting their viewpoints about it. Table 5 . shows the selected experts in specification, educational filed, proficiency, and etc.

Table 5. Experts details

\begin{tabular}{|c|c|c|c|c|}
\hline Name & Gender & Degree & Educational Filed & Proficiency \\
\hline M. E. & Male & Master & $\begin{array}{l}\text { Educational } \\
\text { technology }\end{array}$ & Designing math courseware \\
\hline S. KH. & Female & Master & $\begin{array}{l}\text { Educational } \\
\text { curriculum }\end{array}$ & Mathematics teaching method \\
\hline Z. H. & Female & Ph.D. & $\begin{array}{l}\text { Teaching } \\
\text { mathematics }\end{array}$ & Mathematics teaching method \\
\hline H. M. & Male & Ph.D. & $\begin{array}{l}\text { Educational } \\
\text { technology }\end{array}$ & Designing math courseware \\
\hline S. R. & Male & Master & $\begin{array}{l}\text { Software } \\
\text { engineering }\end{array}$ & Designing math courseware \\
\hline A. $\mathrm{N}$. & Female & Ph.D. & $\begin{array}{l}\text { Teaching } \\
\text { mathematics }\end{array}$ & Mathematics teaching method \\
\hline
\end{tabular}

In this part of study, firstly, the designed check list was sent by a letter to experts. The letter is contained a brief explanation about designing mentioned. Secondly, the experts invited for a discussion meeting after 10 days. In this meeting, each expert explained its own viewpoints to others about contains of checklist. Finally, after the discussion meeting with experts some criteria were crystalized in the sentences and content for better understanding by users. Thus, last version of check list was finalized (see Table 6).

Table 6. Final check list

NO Persuasive Factors

No Partly Good

1 Training is presented step by step with various ways and shapes.

2 Presenting the new educational subjects according to main source.

3 Explaining the necessity of presented subjects, during learning process.

4 The learners' attitude and viewpoints be considered, in learning process.

5 The consistency of the new educational subject with previous knowledge is explained for learner.

Educational messages are presented in all phases of installation and implementation of courseware.

7 During learning process, there is conversation whit learner as written or voice by computer.

The learner can change some content of the training program on the display (such as shapes, colors, movements, etc.)

9 The learner be able to express their emotions, sympathy and compassion in the courseware by written, recording voice and, etc.

10 The learners have these abilities that to personalize the display and change them based on personal interests. 
11 The new educational contents are presented in the appropriate conditions and based on learners' needs in the daily life.

12 Learners learn mathematics into some simulated condition by computer like virtual shopping.

13 Learners receive rewards for their correct answers during learning process.

14 There are the opportunities that learners are enabled to put on their personal arguments and innovations in courseware.

There is an opportunity for learners that are able for making social roles based on

15 social norms in mathematics courseware (like selecting a teacher with especial manner or face, and etc.).

16 The opportunities are provided for students' self-assessment during the learning process.

\section{SUM Scours}

The results are collected from all evaluators. To facilitate the integration data, for three quality checklist options is determined three numbers. So, for option "no" set number 0, "partly" set number 1, and "good" number 2 . As a result, each of courseware that is able to earn more scours, it is more able to persuade primary school students in learning mathematics process. So, table 7 shows earned courseware scours after evaluating by experts. The three courseware were adopted by two experts based on checklist developed in the study. The results of analysis were impressive (see Table 7). Accordingly, the first ranked was Kousha and Nousha, failed to even gain half of the points in the proposed persuasion model at best.

Table 7. Results of courseware analysis by designed check list

\begin{tabular}{|c|c|c|c|c|c|c|}
\hline \multirow{2}{*}{ Courseware Names } & \multirow{2}{*}{ Experts } & \multicolumn{3}{|c|}{ Scours } & \multirow{2}{*}{$\begin{array}{l}\text { Total } \\
\text { scours }\end{array}$} & \multirow{2}{*}{ Avg. } \\
\hline & & No & Partly & Good & & \\
\hline \multirow{3}{*}{ DABESTANIHA } & $\mathrm{A}=$ Courseware designer & 10 & 1 & 5 & 11 of 32 & \multirow{3}{*}{10.66 of 32} \\
\hline & $\mathrm{B}=$ Psychologist & 10 & 2 & 4 & 10 of 32 & \\
\hline & $\mathrm{C}=$ Researcher & 10 & 1 & 5 & 11 of 32 & \\
\hline \multirow{3}{*}{$\begin{array}{l}\text { MISHA } \\
\text { KOOSHA }\end{array}$} & $\mathrm{A}=$ Courseware designer & 7 & 3 & 6 & 15 of 32 & \multirow{3}{*}{14.66 of 32} \\
\hline & $\mathrm{B}=$ Psychologist & 7 & 3 & 6 & 15 of 32 & \\
\hline & $\mathrm{C}=$ Researcher & 8 & 2 & 6 & 14 of 32 & \\
\hline \multirow{3}{*}{ LOHE DANESH } & $\mathrm{A}=$ Courseware designer & 10 & 3 & 3 & 9 of 32 & \multirow{3}{*}{9 of 32} \\
\hline & $\mathrm{B}=$ Psychologist & 10 & 3 & 3 & 9 of 32 & \\
\hline & $\mathrm{C}=$ Researcher & 10 & 3 & 3 & 9 of 32 & \\
\hline
\end{tabular}

\section{Discussion}

As pointed out in the literature review, learning and training mathematics have been always a challenge in education (Hoyles \& Lagrange, 2009; Zeidner \& Matthews, 2010). Add to this challenge the negative attitudes toward the course and poor educational achievements in mathematics that are of great importance. As it discussed, studies have highlighted specific issues with the student's attitude and shortcoming of math education methods. This introduction portrays necessity of the study as the main aim is to evaluate persuading features in mathematics courseware by a check list. Qualitative and quantitative research methods were employed to reach this aim. First step was to elaborate on the previous models, theories, and approaches in the persuasion. Based on the preliminary studies, 13 models, theories, and approaches were identified. These are the methods that try to persuade individuals or to change their attitudes, each of which adopted in different fields of sociology. Indeed, none of the models, theories, and approaches has been specifically designed to be used in educational 
environment. However, the fact that human is the main factor in all of them, makes them suitable for our study. In the rest of the study, the previous models are analyzed using Content Analysis methods - a qualitative research method. The second step of the study requires extracting the principal rules of the 13 models. This was done by the way of an accurate study and analysis of the content of each model. The results of the surveys at these stages were 38 principles that constitute the previous models. It must be mentioned that some of the principals are common among the models. By omitting repetition of principals, we continued the research with 16 rules. The check list was designed based on these 16 criteria. At the final step, three more popular mathematics training software were prepared and analyzed based on a persuasive principles check list. The results of the analysis have shown the extent to which the rules introduced in the proposed check list have been used by the developers of the mathematics courseware. But, the results have shown the most popular mathematics courseware which its name is "Kosha \& Misha", could only earned approximately half the points of check list. It means, more than half of persuading factors are not included in the most popular courseware. Two others mathematics courseware only be able to obtain a third of points. Totally, with a brief look at these results, it can be concluded that, with regard to the persuasion issue, perhaps we will be able to overcome negative attitudes toward mathematics in school students. We hope to see better persuasive point in the mathematics courseware by using the applied results of this study in schools.

\section{References}

Aiken, Lewis R. (1970). Attitudes toward mathematics. Review of educational research, 40(4), 551-596.

Ajzen, I., \& Sozialforschung, Mannheimer Zentrum für Europäische. (2000). The theory of planned behavior: habit, perceived control, and reasoned action: Mannheimer Zentrum für Europäische Sozialforschung.

Beghetto, Ronald A. (2010). Creativity in the classroom. The Cambridge handbook of creativity, 447-463.

Bersin, Josh. (2004). The blended learning book: Best practices, proven methodologies, and lessons learned: John Wiley \& Sons.

Borasi, Raffaella. (1996). Reconceiving mathematics instruction: A focus on errors: Greenwood Publishing Group.

Cameron, Kenzie A. (2009). A practitioner's guide to persuasion: An overview of 15 selected persuasion theories, models and frameworks. Patient Education and Counseling, 74(3), 309-317.

Chaiken, S., \& Trope, Y. (1999). Dual-Process Theories in Social Psychology. Guilford Press.

Connor, D. F. (2012). Aggression and Antisocial Behavior in Children and Adolescents: Research and Treatmen. Guilford Publications.

Creemers, Bert PM, \& Reezigt, Gerry J. (2005). Linking school effectiveness and school improvement: The background and outline of the project. School Effectiveness and School Improvement, 16(4), 359-371.

Dogan, Hamide. (2012). Emotion, confidence, perception and expectation case of mathematics. International Journal of Science and Mathematics Education, 10(1), 49-69.

Ernest, P., Greer, B., \& Sriraman, B. (2009). Critical Issues in Mathematics Education: Information Age Pub Incorporated.

Festinger, L. (1957). A theory of cognitive dissonance. Stanford University Press.

Fishbein, M., \& Ajzen, I. (1975). Belief, attitude, intention, and behavior: an introduction to theory and research: Addison-Wesley Pub. Co.

Fogg, B. J. (2003). Persuasive technology: using computers to change what we think and do. Morgan Kaufmann Publishers.

Gunderson, Elizabeth A, Ramirez, Gerardo, Levine, Susan C., \& Beilock, Sian, L. (2012). The role of parents and teachers in the development of gender-related math attitudes. Sex Roles, 66(3-4), 153-166.

Heider, F. (1982). The psychology of interpersonal relations. Lawrence Erlbaum Associates.

Hong, Zuway, R. (2010). Effects of a collaborative science intervention on high achieving students' learning anxiety and attitudes toward science. International Journal of Science Education, 32(15), 1971-1988.

Hossain, Md Mokter, \& Quinn, Robert, J. (2013). Investigating Relationships between Attitudes toward the use of Web 2.0 Technologies and Mathematical Achievement. Paper presented at the Society for Information Technology \& Teacher Education International Conference. 
Hovland, C. I., Janis, I. L., \& Kelley, H. H. (1953). Communication and persuasion: psychological studies of opinion change. Greenwood Press.

Hoyles, C., \& Lagrange, J. B. (2009). Mathematics Education and Technology-Rethinking the Terrain: The 17th ICMI Study. Springer.

Kail, R. V., \& Cavanaugh, J. C. (2012). Human Development: A Life-Span View. Cengage Learning.

Katz, D. (1960). The functional approach to attitudes. Public Opin Q24, 41.

Lim, Siew Yee, \& Chapman, Elaine. (2013). Development of a short form of the attitudes toward mathematics inventory. Educational Studies in Mathematics, 82(1), 145-164.

McCoach, D Betsy, \& Siegle, Del. (2001). A comparison of high achievers' and low achievers' attitudes, perceptions, and motivations. Academic Exchange, 2, 71-76.

McGuire, W. J. (1964). Inducing resistance to persuasion: some contemporary approaches. New York: Academic Press.

McGuire, W. J. (1981). The probabilogical model of cognitive structure and attitude change. In R. Petty, T. Ostrom, \& T. Brock (Eds.), Cognitive responses in persuasion. Hillsdale, NJ: Erlbaum.

Neuendorf, Kimberly A. (2002). The content analysis guidebook. Sage.

Perloff, R. M. (2010). The dynamics of persuasion: communication and attitudes in the 21st century: Routledge.

Petty, R. E., \& Cacioppo, J. T. (1986). Communication and persuasion: central and peripheral routes to attitude change. Springer-Verlag.

Pierce, R., \& Stacey, K. (2004). A framework for monitoring progress and planning teaching towards the effective use of computer algebra systems. International Journal of Computers for Mathematical Learning, 9, 59-93.

Pilli, Olga, \& Aksu, Meral. (2012). The effects of computer-assisted instruction on the achievement, attitudes and retention of fourth grade mathematics students in North Cyprus. Computers \& Education.

Reed, Helen C, Drijvers, Paul, \& Kirschner, Paul A. (2010). Effects of attitudes and behaviours on learning mathematics with computer tools. Computers \& Education, 55(1), 1-15.

Sankofa, Biko Martin, Hurley, Eric A, Allen, Brenda A., \& Boykin, A Wade. (2005). Cultural expression and Black students' attitudes toward high achievers. The Journal of Psychology, 139(3), 247-260.

Schoenfeld, A. H. (1985). Mathematical problem solving. Academic Press.

Scott, W. A. (1955). Reliability of content analysis: The Aace of Nominal Scale Coding. Public Opinion Quarterly, 19(3), 5.

Sherif, C. W., Sherif, M., \& Neber- gall, G. (1965). Attitude and Attitude Change. Philadelphia: Saunders.

Silverman, Stephen, \& Subramaniam, Prithwi Raj. (1999). Student attitude toward physical education and physical activity: a review of measurement issues and outcomes. Journal of teaching in physical education, 19(1), 97-125.

Smith, M. B. , Bruner, J. S. , \& White, R. W. (1956). Opinions and personality. New York: John Wiley.

Stipek, Deborah J., \& Gralinski, J Heidi. (1991). Gender differences in children's achievement-related beliefs and emotional responses to success and failure in mathematics. Journal of Educational Psychology, 83(3), 361.

Tall, David. (1993). Success and failure in mathematics: the flexible meaning of symbols as process and concept. Mathematics Teaching, 14, 6-10.

Triandis, H. C. (1989). Current theory and research in motivation: University of Nebraska Press. Dept. of Psychology.

Van de Grift, WJCM, \& Houtveen, AAM. (2006). Underperformance in primary schools. School Effectiveness and School Improvement, 17(3), 255-273.

Vandewaetere, Mieke, Desmet, Piet, \& Clarebout, Geraldine. (2011). The contribution of learner characteristics in the development of computer-based adaptive learning environments. Computers in Human Behavior, 27(1), 118-130. 
Wendling, B. J., \& Mather, N. (2008). Essentials of Evidence-Based Academic Interventions. John Wiley \& Sons.

Wong, Khoon Yoong, \& Chen, Qian. (2012). Nature of an Attitudes toward Learning Mathematics Questionnaire. Mathematics education: Expanding horizons, 793-800.

Yamada, Masanori. (2009). The role of social presence in learner-centered communicative language learning using synchronous computer-mediated communication: Experimental study. Computers \& Education, 52(4), 820-833.

Zakaria, Effandi, Chin, Lu C., \& Daud, Md Y. (2010). The Effects of Cooperative Learning on Students' Mathematics Achievement and Attitude towards Mathematics. Journal of Social Sciences, 6(2), 272.

Zeidner, M., \& Matthews, G. (2010). Anxiety 101. Springer Publishing Company.

\section{Copyrights}

Copyright for this article is retained by the author(s), with first publication rights granted to the journal.

This is an open-access article distributed under the terms and conditions of the Creative Commons Attribution license (http://creativecommons.org/licenses/by/3.0/). 